\title{
Entropi Temelli TOPSIS ve VIKOR Yöntemleri ile Bankacılık Sektöründe Finansal Performans Değerlendirmesi ${ }^{1}$ \\ Ökkeş YILMAZ ${ }^{2}$ Emre YAKUT ${ }^{3}$
}

\begin{tabular}{ccc}
\hline Geliş Tarihi/ Received & Kabul Tarihi/ Accepted & Yayın Tarihi/ Published \\
04.02.2021 & 22.09.2021 & 15.10 .2021 \\
\hline Citation/Atıf: Yılmaz Ö. ve Yakut E., (2021), Entropi Temelli TOPSIS ve VIKOR Yöntemleri ile Bankacıllk \\
Sektöründe Finansal Performans Değerlendirmesi, Atatürk Üniversitesi İktisadi ve İdari Bilimler Dergisi, \\
35(4): Sayfa: $1297-1321$, https://doi.org/10.16951/atauniiibd.874660
\end{tabular}

Öz: Bankacılık sektörü finansal sistemin önemli bir parçası olarak yer alır. Bankacılık sektörünün kaynak dağılımı ve finansal aracılık görevi açısından etkin ve verimli çalıșması, ülke ekonomisi açısından çok önemlidir. Dolayısıyla ekonomiler içerisinde oldukça kritik noktada bulunan bankaların finansal performanslarının değerlendirilmesi büyük öneme sahiptir.

Bu çalışmada; Borsa İstanbul (BİST)'da işlem gören 22 bankanın 2009-2018 yılları arası finansal performanslarının, Topsis ve Vikor çok kriterli karar verme yöntemleri ile değerlendirilerek belirlenmes amaçlanmıștır. Calıșmada 26 adet kriter kullanılmıștır. Kullanılan kriterlerin ağırlıkları Entropi yöntemiyle hesaplanmıştır. Daha sonra Topsis ve Vikor yöntemleriyle performans analizi yapılmış, değerlendirme sonucunda her iki yöntemde de ilk üç sırada aynı bankaların yer aldığı tespit edilmiștir. "Likit Aktifler / Kısa Vadeli Yükümlülükler" oranı en yüksek değeri alan kriter olarak elde edilmiştir. Bankalar bazında incelendiğinde alt sıralarda kalan bankalarda bu oranın düşük olduğu gözlemlenmiştir. Bankaların öne çıkan maksimum yönlü kriterler ile ilgili banka yapısını güçlendirici ve öne çıkan minimum yönlü kriterler ile ilgili de düşük seviyede tutacak çalışmalar yapmaları önerilebilir.

Anahtar Kelimeler: Entropi Yöntemi, VIKOR Yöntemi, TOPSIS Yöntemi, Finansal Performans

Evaluation of Financial Performance in Banking Sector Using Entropy Based TOPSIS and VIKOR Methods

Abstract: The banking sector is an important part of the financial system. The effective and efficient function of the banking sector, in terms of the duties of distribution of resources and financial mediation, is rather important for the national economy. Therefore, it is of great importance to evaluate the financial performance of banks, which are at critical points in economies.

In this study, it was aimed to evaluate the financial performances of 22 banks, which operated in Borsa Istanbul (BIST) from 2009 to 2018, by using the Topsis and Vikor multi-criteria decision-making methods. In the study, 26 criteria were taken into consideration. The weights of the criteria that were used in the study were calculated by using the Entropy method. Then, performance analyses were conducted by using the Topsis and Vikor methods. The findings highlight that the same banks were in the first three places in the both methods. The ratio of "Liquid Assets / Short Term Liabilities" has been obtained as the criterion that gets the highest value. When analyzed on the basis of banks, it is observed that this ratio is low in banks that are in the lower ranks. It may be suggested that banks should carry out studies that will strengthen the bank structure related to the prominent maximum directional criteria and keep the minimum directional criteria at a low level.

Keywords: Entropy Method, VIKOR Method, TOPSIS Method, Financial Performance

Jel Codes: C02, C44, G21

${ }^{I}$ Not: Bu çalışma, Doç. Dr. Emre YAKUT danışmanlı̆̆ında, Osmaniye Korkut Ata Üniversitesi Sosyal Bilimler Enstitüsünde yürütülen doktora tez çalıșmasından türetilmiștir.

${ }^{2}$ Dr., yilmazokkes27@gmail.com,https://orcid.org/0000-0001-9638-942

${ }^{3} \mathrm{Dr}$. Öğr. Üyesi, Osmaniye Korkut Ata Üniversitesi, İktisadi ve İdari Bilimler Fakültesi, Yönetim Bilişim

SistemleriBölümü, emreyakut@osmaniye.edu.tr, https://orcid.org/0000-0002-1978-0217 
Entropi Temelli TOPSIS ve VIKOR Yöntemleri ile Bankacllk Sektöründe Finansal Performans Değerlendirmesi

\section{EXTENDED SUMMARY}

\section{Background}

It is important for banks to evaluate their financial performance, to continue their economic activities in rapidly changing environmental conditions with global uncertainties, in terms of economic growth and efficiency. Banks also need an effective performance analysis in order to be always prepared against economic uncertainties, troubles and crises or to display a more successful economic performance and to achieve sustainable growth.

In this study, financial performance analysis will be performed for banks traded in BIST using classic multi-criteria decision making methods with data obtained from the website of the Turkish Banks Association.

\section{Purpose}

In this study, it was aimed to evaluate the financial performances of 22 banks traded on Borsa Istanbul (BIST) between 2009-2018 with classical multicriteria decision making methods. Furthermore, in the study, it was aimed to determine the method that stands out from the classical multi-criteria decision making methods. It is expected that the data obtained as a result of the analysis in the study will contribute to the financial performance of the Turkish banking sector.

\section{Method}

In the study, 10-year data of 22 banks traded on Borsa Istanbul (BIST) between 2009-2018 were used. By calculating the criteria weights with the entropy method, the performance analysis of the banks was made with the TOPSIS method and the VIKOR method, and the ranking results were evaluated. In this context, the criteria set was determined as a result of the literature review and 26 financial criteria were created. Accordingly, the financial performances of the banks were calculated and the ranking results of the methods used were compared.

\section{Findings}

Entropy method was used in calculating the criteria weights for evaluating the financial performance of banks. Among these criteria, the "Liquid Assets/Short Term Liabilities" ratio was calculated as the first criterion with the highest weight, while the "Received Loans/Total Assets" ratio ranked second. "Equity/(Loan + Market + Sum as a Basis for Operational Risk)" ratio ranked third. Similarly, it was revealed that the weights calculated for capital adequacy and liquidity ratios took values with higher weights compared to other financial ratios.

When the financial performances of banks were analyzed with the methods used, Adabank ranked first, Birleşik Fon Bankası second and CITIBANK ranked 
third in both Topsis and VIKOR methods. While it was determined that these three banks performed better than other banks, Ziraat Bank took the fourth place in TOPSIS method and ARAPTÜRK bank took the fourth place in VIKOR method. On the other hand, it was revealed that DEUTSCHE Bank and ING Bank in TOPSIS method and Alternatifbank and Denizbank in VIKOR method took the last two rankings.

\section{Conclusions}

When an evaluation is made in terms of improving the financial performance of banks, it will be beneficial for banks with low "Liquid Assets / Short-Term Liabilities" and "Borrowed / Total Assets" ratios to keep these criteria at a minimum level in terms of financial indicators so that they do not have payment difficulties in case of a possible crisis. Similarly, it can be stated that having a good level of "Capital Adequacy" is important for banks. It is recommended that banks should carry out studies that will strengthen the bank structure related to the maximum directional criteria and keep the minimum directional criteria at a low level.

\section{Giriş}

Bankacıllk sektörü ülkemizde finansal sistemin önemli bir parçası olarak yer alır. Bankacılık faaliyetlerinin etkin ve verimli bir şekilde yerine getirilmesi ekonomik istikrarın sağlanmasında önemli bir role sahiptir. Bankalar finansal sistemin sıkıntılarından, etkin olmayan para ve maliye politikalarından, uluslararası ilişkilerden, döviz kurlarındaki ani değişimlerden ve enflasyon rakamları gibi birçok değişkenden etkilenebilmektedir. Bankaların finansal sistemdeki pozisyonu nedeniyle bankacıllk sektöründe meydana gelebilecek herhangi bir olumsuzluk tüm ülke ekonomisini etkileyebilmektedir (Yakut, 2019: 195).

Birbirleriyle komşu dahi olmayan ülkeler, küreselleşmeyle birlikte finansal sektörde sermaye hareketlerinin etkilerini daha çok hissetmektedirler. Finansal sektördeki rekabetin artmasıyla birlikte uluslararası ölçekteki finansal kuruluşlar, diğer ülkelerdeki büyük ölçekli kuruluşlarla stratejik ortaklıklara yönelirken, ulusal bazda ise bankalar kendi içinde birleşme ve devir gibi stratejilere yönelmiştir (Tezergil, 2016: 358). Bankacılık sektöründe süren rekabet ortamı, bankaların mevcut sermayelerini verimli kullanmalarını gerektirmektedir. Bankaların faaliyetini sürdürebilmesi, ülke ekonomisi açısından çok önemlidir.

Bankalar; ekonomik işlevleri, yapmış oldukları işlemlerin ve sunmuş oldukları hizmetlerin niteliği, karşılaşmış oldukları risklerin çeşitliliği, faaliyetlerini yasalarla ya da idari kararlarla düzenlemesi, kamu otoritelerinin denetim ve gözetimi altında tutulmaları ve son olarak küreselleşmeden belki de en fazla etkilenen finans sektöründe faaliyette bulunuyor olmaları gibi nedenlerle diğer işletmelerden ayrılmaktadır. Bankalarda performans analizinde kullanılan 
Entropi Temelli TOPSIS ve VIKOR Yöntemleri ile Bankacllk Sektöründe Finansal Performans Değerlendirmesi

teknikler, farklı bir bakış açısını, değerlendirme ve yorumları gerektirmektedir (Gazel, 2019: 1). Hem finansal sistem hem de ekonomi üzerindeki etkisi dikkate alındığında bankaların seçimine ilişkin performanslarının belirlenmesi karar vericiler açısından önemlidir. Bankalar arasındaki rekabetçi durum ve yatırımcılar için hizmet kalitesinin iyileştirilmesi zorunluluğu performans değerlendirme çalışmalarını zorunlu hale getirmektedir. Bankaların performanslarının değerlendirilmesinde birçok yöntem kullanılmaktadır. Çok kriterli karar verme yöntemleri, tüm kriterleri kullanarak, mevcut alternatifler içerisinden karar problemine uygun bir modelle problem çözmeyi gerektirdiği için bankaların performanslarının değerlendirilmesini sağlamaktadır (Yakut, 2019: 196). Çok kriterli karar verme tekniklerini kullanmadaki temel neden çok sayıda değerlendirme faktörü olduğunda, değerlendirme ile birlikte karar mekanizmasının kontrolünü sağlamak ve karar sonucunu mümkün olduğunca hızlı bir şekilde neticelendirmektir (Akçakanat vd., 2017: 286).

Bu çalışma ile; Entropi yöntemiyle kriter ağırlıkları belirlenerek, Topsis ve Vikor yöntemleriyle Borsa İstanbul (BİST)'da işlemlerine devam eden 22 bankanın 2009-2018 yılları arası finansal performanslarının değerlendirilmesi amaçlanmıştır. Çalışmada 26 adet kriter ile uygulama yapılmıştır. 2009-2018 yılları arasında tüm verilerine ulaşılamayan bankalar ve bu yıllar arasında süreklilik göstermeyen veriler kriter olarak uygulamada kullanılmamıştır. Bankaların finansal performansının aynı kriterler açısından değerlendirilmesi amaçlanmıştır. Çalışmada kullanılan verilere BİST ve Türkiye Bankalar Birliği tarafindan yayınlanan verilerden ulaşılmıştır.

Çalışma beş bölüm olarak hazırlanmıştır. Birinci bölümde giriş kısmı, ikinci bölümde ise literatür taraması anlatılmıştır. Üçüncü bölüm uygulamada kullanılan Entropi yöntemi, Topsis yöntemi ve Vikor yönteminden oluşmaktadır. Dördüncü bölümde ise kriterler ve veri seti tanıtılarak, uygulama sonuçlarına yer verilmiştir. Beşinci bölümde ise sonuçlar ile öneriler kısmı bulunmaktadır.

\section{Literatür Taraması}

Demireli'nin (2010) çalışmasında; Topsis yöntemiyle 2001-2007 yılları arası Türkiye'deki kamu bankalarının performansları incelenmiştir. Her bir kritere eşit düzeyde ağırlık verilmiştir. Sonuç olarak finansal krizlerin bankaların performansını etkilediği ve önemli görülebilecek bir iyileşme olmadığı ifade edilmiştir.

Dinçer ve Görener'in (2011) çalışmalarında, bankaların performans ölçümü yapılmıştır. Kriterlerinin ağırlıkları AHP ile hesaplanmıştır. Sermaye yeterliliği ve Likidite oranlarının öne çıtığı görülmüştür. Vikor ve Topsis yöntemlerinin her ikisinde de yabancı sermayeli bankaların diğer gruplara göre iyi performans gösterdiği sonucuna ulaşı1mıştır. 
Bağc1 (2013), bu çalışmada; Türk bankacılık sektörünün kârlılık performanslarının 2003-2011 yılları arasının kiyaslanması amaciyla 4 katılım bankası ve 4 ticari bankanın kârlılık performansları incelenmiştir. Bu analizde Topsis yöntemi kullanılmıştır. Analiz sonucunda, katılım bankalarının iyi performans gösterdiği, ticari bankaların ise katılım bankalarına göre düşük performans gösterdiği belirtilmiştir.

Ömürbek, Karaatlı ve Yetim (2014), çalışmada AHP, Topsis ve Vikor yöntemlerini kullanmışlardır. Bu çalışmada ADIM üniversitelerinin performans değerlemesi yapılmıştır. Anadolu'da yer alan 14 üniversiteden, 1993 yılında kurulan 10 üniversite çalışmada değerlendirilmiştir. Çalışmada kullanılan 21 kriterin ağırlıkları AHP ile belirlenmiştir. Topsis ve Vikor yöntemleriyle uygulama yapılmıştır. Her iki yöntem sonucunda da Süleyman Demirel Üniversitesi birinci sırada yer almıştır.

Kandemir ve Karataş (2016), BİST’teki 12 bankanın 2004-2014 yılları arası performanslarını ÇKKV yöntemlerinden, GİA, Topsis ve Vikor yöntemleri ile incelemişlerdir. Sonuç olarak; GİA ve Topsis yöntemlerine göre, performans değeri en iyi olan bankanın Vakıfbank, performans değeri en düşük olan bankanın ise Şekerbank olduğu sonucuna ulaşılmıştır. Vikor yöntemine göre ise performans değeri en iyi olan banka Denizbank, performans değeri en düşük olan banka Tekstil Bank olmuştur.

Özel (2016), bu çalışmada Topsis yöntemi ile 3'ü kamusal, 11'i özel ve 10 'u yabancı sermayeli toplam 24 bankanın 2006-2014 yılları arası finansal performansları analiz edilmiştir. Analize göre birinci sırayı ADABANK'ın aldığı, son sırayı ise FIBABANK'ın aldığ görülmüştür. Bütün sonuçlara bakıldığında ise özel sermayeli bankaların daha yüksek performans değerlerine sahip oldukları görülmektedir. Çalışma kamu bankaları kendi arasında incelendiğinde Halkbank, Özel bankalar dikkate alındığında Adabank ve yabancı bankalara bakıldığında ise Deutsche Bank ve Citibank'ın öne çıktığı görülmektedir. Tüm sonuçlar dikkate alındığında ise en yüksek puanlara sahip bankaların Adabank ve Deutsche Bank olduğu görülmektedir. Genel olarak Adabank en başarılı olan banka iken Deutsche Bank'ın yıllara göre çok dalgalanma gösterdiği görülmektedir.

Tezergil (2016), 2009-2013 yı1ları arası 28 bankanın finansal performanslarını, Vikor yöntemiyle değerlendirmiştir. Çalışmada her bir kriter eşit ağırlıklı olarak düşünülmüştür. Vikor ile yapılan sıralamada 2013 yılında Citibank'ın birinci sırayı aldığı, 2011 ve 2012 yılında Ziraat Bankası'nın, 2009 ve 2010 yılında ise Akbank'ın en iyi performans gösterdiği sonuçları elde edilmiştir. Tezergil, elde edilen sonuçlarda tutarlılık olmasından dolayı Vikor yönteminin bankalar arasında performans sıralamalarında kullanılabilecek bir yöntem olduğunu vurgulamıştır. 
Entropi Temelli TOPSIS ve VIKOR Yöntemleri ile Bankacllk Sektöründe Finansal Performans Değerlendirmesi

Akçakanat vd.(2017), bu çalışmada aktif büyüklüğü durumlarına bakılarak, bankaların performansları Entropi ve WASPAS yöntemleriyle değerlendirilmiştir. Kriter ağırlıkları Entropi yöntemi kullanılarak elde edilmiş, WASPAS yöntemiyle değerlendirme yapılarak bankaların sıralaması yapılmıştır. Sonuç olarak; büyük, orta ve küçük ölçekli bankalardan performansı en iyi olanlar sırasıyla Ziraat Bankası, Finans Bank ve Anadolu Bank olmuştur.

Özkan (2017), çalışmada 7 bankanın performanslarını ÇKKV yöntemlerinden Topsis yöntemiyle belirlemeye çalışmıştır. Seçilen finansal oranlar eşit olarak ağırlıklandırılmış ve ağırlıklar 0,1 olarak alınmıştır. Analiz sonucunda performanslar incelendiğinde herhangi bir bankanın bariz üstünlüğü görülmemiş ancak performans puanlarının ortalamasına göre bakıldığında Garanti Bankası birinci sırayı alırken Akbank son sırada yer almıştır.

Aldemir (2018), araştırmada ÇKKV yöntemlerinden Topsis ve Vikor yöntemi yardımıyla mevduat bankalarının son beş yıldaki finansal performansları değerlendirilmiş ve analiz edilmiştir. Türkiye'de 2012-2016 yılları arasında faaliyetine devam eden 21 mevduat bankasının performansı değerlendirilmiştir. Çalışma yıllara göre incelenmiştir ancak genel sıralamaya bakıldığında ilk sırada Citibank yer almıştır. Akbank ikinci, Ziraat Bankası üçüncü, Garanti Bankası dördüncü ve Halk Bankası beşinci sırada yer almıştır. Son beş sırada ise sırasıyla ING Bank, Alternatif Bank, HSBC Bank, Fibabanka ve Burgan Bank sıralanmıştır.

Yalçıner ve Karaatlı (2018), çok kriterli karar verme yöntemleriyle 20022015 yılları arasında 25 mevduat bankasının performansını değerlendirmiştir. Çalışmada kriterlerin ağırlıkları AHP ile belirlenmiş, Topsis ve Electre yöntemleriyle banka seçimi ele alınmıştır. Çalışma sonucunda Ziraat Bankası'nın iki yöntemde de ilk sırada olduğu görülmüştür.

Akgül (2019)'ün çalışmasında; Entropi, SAW, MAUT ve ARAS yöntemlerinin kullanılmasıyla, 2010-2018 yılları aras1 banka performans değerlendirmesi yapmıştır. Entropi yöntemi sonuçlarıyla, "Likit Aktifler/Kısa Vadeli Yükümlülükler", "Duran Varlıklar/Toplam Varlıklar" ve "Alınan Krediler/Toplam Varlıklar" öne çıkan kriterler olmuştur. Daha sonra SAW, MAUT ve ARAS yöntemleriyle analiz yapıldığında üç modelde de yıllara ilişkin performans sıralamasının aynı olduğu ifade edilmiştir. Sonuç olarak, bankaların 2010 yılı performanslarının en iyi olduğu, 2018 yılının ise en düşük olduğu belirlenmiştir.

Altemur, Çevik ve Karaca (2019), Borsa İstanbul'daki (BİST 30 endeksi) 6 banka 20 adet finansal oran kullanılarak TOPSIS yöntemiyle incelenmiştir. Analiz sonuçlarında göre ilk üç sırada "Akbank", "Garanti Bankası" ve "İ̧̧ Bankası" yer almıştır. 
Özkan (2019), bu çalışmada, Topsis yöntemiyle Borsa İstanbul'daki 10 bankanın 2013-2017 dönemindeki performans değerlendirmesi 10 adet finansal oran kullanılarak yapılmıştır. Analiz sonucunda performans olarak, QNB Finansbank ve Halk Bankası'nın ilk iki sırayı aldığı görülmüştür.

Topak ve Çanakçığlu (2019), Türkiye'deki 11 bankanın 2017 yılındaki performansının değerlendirilmesinde Entropi ve COPRAS yöntemlerini kullanmışlardır. Entropi yöntemi kullanılarak kriter ağırlıkları belirlenmiştir. COPRAS yöntemiyle de bankaların performans sıralaması elde edilmiştir. Sonuç olarak performansı en yüksek bankalar Ziraat Bankası, İş Bankası ve Garanti Bankası olarak belirtilmiştir.

Yakut (2019); çalışmada Türkiye'de 2014-2018 yılları arasında bankacılık işlemlerinde süreklilik arz eden 21 mevduat bankasının performanslarının belirlenmesi amaçlanmıştır. Sekiz kriter kullanılmış her bir kriter Entropi yöntemi ile ağırlıklandırılmış ve Topsis yöntemine göre bankalar sıralanmıştır. Topsis yöntemiyle sıralanan bankalar performanslarına göre yüksek, orta ve düşük olmak üzere gruplandırılmıştır. Bankalar içerisinden en iyi performans gösteren banka Ziraat Bankası olarak ifade edilmiştir.

\section{Metodoloji}

Çalışmada; Borsa İstanbul (BİST)'da işlemlerini sürdüren 22 bankanın 2009-2018 arası performansları 26 adet kriter ile değerlendirilmiştir. Analiz için Entropi yöntemi, Topsis yöntemi ve Vikor yöntemi kullanılmıştır.

\subsection{Entropi Yöntemi}

Entropi kavramını Rudolph Clausius, sistem içerisindeki belirsizlik ve düzensizlik ölçümü şeklinde tanımlanmıştır. Daha sonra Shannon'un çalışmalarıyla geliştirilmiştir (Akgül, 2019: 572). Entropi, termodinamiğin bir konusudur. Entropi yöntemiyle hazır verinin sağladığ 1 faydalı bilginin miktarı ölçülmektedir (Yakut, 2019: 198). Çınar (2004)'a göre; Entropi yönteminde ana fikir, nitelik değere ilişkin bilginin veri kümelerindeki zitlıklardan geldiği şeklindedir. Bu zıtlık ne kadar fazla olursa kriterlere ait nesnel ağırlık o kadar fazla olmaktadır (Ömürbek vd., 2016: 238).

Entropi yöntemi kriter ağırlıklarının hesaplanmasında kullanılmaktadır. Shannon ve Weaver (1948)'a göre; entropi bilgi içerisindeki belirsizliğin ölçümü şeklinde açıklanmıştır (Abdullah ve Otheman, 2013: 26).

Entropi yönteminin aşamaları adımlar halinde açıklanmıştır (Yakut, 2019: 199; Wang - Lee, 2009: 8982; Akgül, 2019: 572):

1.Adım: Karar matrisi oluşturulur. 
Entropi Temelli TOPSIS ve VIKOR Yöntemleri ile Bankacıllk Sektöründe Finansal Performans Değerlendirmesi

$$
\begin{gathered}
E_{i j}=\left[\begin{array}{cccc}
e_{11} & e_{12} & \ldots & e_{1 n} \\
e_{21} & e_{22} & \ldots & e_{2 n} \\
\ldots & \ldots & \ldots & \ldots \\
e_{m 1} & e_{m 2} & \ldots & e_{m n}
\end{array}\right] \\
i=1,2, \ldots, m \text { (alternatifler) } v e j=1,2, \ldots, n \text { (kriterler) }
\end{gathered}
$$

2.Adım: Karar Matrisinin Normalize Edilmesi.

Karar matrisinin elemanları fayda ve maliyet durumlarına göre aşağıdaki eşitlikler yardımıyla standartlaştırılmaktadır.

$$
\begin{aligned}
a_{i j}=\frac{e_{i j}}{\max _{i j}} & i=1,2, \ldots, \text { m ve } j=1,2, \ldots, n \\
a_{i j}=\frac{\min _{i j}}{e_{i j}} & i=1,2, \ldots, m \text { ve } j=1,2, \ldots, n
\end{aligned}
$$

Standartlaştırma işleminin ardından normalizasyon işlemi aşağıdaki eşitlikle yapılır.

$$
P_{i j}=\frac{a_{i j}}{\sum_{i=1}^{m} a_{i j}}
$$

$p_{i j}$ : Normalize edilmiş değerler

$a_{i j}$ : Verilen fayda değerleri

3.Adım: Entropi değerleri hesaplanır.

Her bir kritere ilişkin entropi değeri aşağıda verilen eşitlikler yardımıyla bulunur.

$$
\begin{aligned}
e_{j} & =-k \cdot \sum_{i=1}^{m} p_{i j} \cdot \ln \left(p_{i j}\right) \\
k & =(\ln (m))^{-1}
\end{aligned}
$$

$\mathrm{k}$ : Entropi değeri katsayısını

$e_{j}:$ Entropi değerini

$p_{i j}$ : Normalize değerleri ifade eder.

Kriterlerin Entropi $\left(e_{j}\right)$ değeri "1" e yaklaştıkça ilgili kriterin karar problemi için önemi azalmaktadır.

4.Adım: Her bir kriter için sapma değerleri aşağıda verilen eşitlik yardımıyla elde edilir.

$$
d_{j}=1-e_{j}
$$

$d_{j}$ değeri $j$ kriterinin ayrım gücünü ifade eder. $d_{j}$ değerinin yüksek olması $j$ kriterinin karar verme problemi açısından ayrım gücünün artması, yani önem seviyesinin yükselmesi anlamına gelmektedir.

5. Adım: Her bir kriter için ağırlık değerleri hesaplanır.

$$
w_{j}=\frac{d_{j}}{\sum_{j=1}^{n} d_{j}}
$$




$$
\sum_{j=1}^{n} w_{j}=1 ; \quad j=1,2, \ldots, n
$$

\subsection{Topsis Yöntemi}

Yoon ve Hwang (1981) Topsis yöntemini; çözüm alternatifinin, pozitif ideal çözüme en yakın olan ve negatif ideal çözüme en uzak olan noktayı açılayarak ifade etmişlerdir (Demireli, 2010: 104). Yani, yöntem ideal çözüme yakınlığa göre alternatiflerin sıralanması temeline dayanmaktadır. (Cheng ve Wang, 2001: 465). Yüksek olması istenilen özelliklerin maksimum, düşük olması istenilen özelliklerin minimum olduğu çözüm ideal çözüm olarak ifade edilebilir. İdeal çözümün uygulanamadığ 1 ya da ideal çözüme ulaşılamadığ durumda ideal çözüme en yakın değerin alınması gerekir. Pozitif-ideal çözüm, ideale en yakın çözümken, negatif-ideal çözüm ise ideale en uzak olan çözüm şeklinde ifade edilir (Özgüven, 2011: 155).

Topsis, direkt veri üzerinden uygulanabilen bir yöntemdir. Aynı zamanda her bir kriterin artan veya azalan fayda eğilimi olduğunu kabul etmektedir. Bu yüzden, ideal çözüm ile negatif-ideal çözümü tanımlamak kolay olmaktadır. Pozitif ideal çözüm maliyet kriterini minimize ederken, fayda kriterini maksimize etmeye çalışan çözümü esas almaktadır. Negatif ideal çözümde ise fayda kriterini minimize ederken, maliyet kriterini maksimize etmeye çalışan çözüm olarak ifade edilir (Dağdeviren, vd., 2009: 8145).

Aşağıda TOPSIS yönteminin işlem adımları açıklanmıştır (Özdemir, 2015: 135-139; Opricovic ve Tzeng, 2004: 448; Y1lmaz, 2012: 37-40):

1.Adım: Karar Matrisi Oluşturulur: Karar matrisi satırları alternatiflerden ve sütunları karar vermede kullanılan kriterlerden oluşan matristir. Karar matrisi (A) $m x n$ tipindedir.

2.Adım: Standart Karar Matrisi Oluşturulur (Normalizasyon): Normalizasyon işlemi, karar matrisi kullanılarak formül (9) yardımıyla elde edilir.

$$
y_{i j}=\frac{\frac{1}{a_{i j}}}{\sqrt{\sum_{k=1}^{m} \frac{1}{a_{k j}^{2}}}}
$$

3. Adım: Ağırlıklandırılmış Standart Matris Oluşturulur: Normalize edilmiş matrisin her bir sütun elemanları ile ilgili kriter ağırlığı $\left(w_{i}\right)$ çarpılarak ağırlıklı standart matris (V) elde edilir.

4. Adım: İdeal $\left(\mathrm{A}^{*}\right)$ Çözüm ve Negatif İdeal $\left(\mathrm{A}^{-}\right)$Çözüm Hesaplanır: İdeal çözüm seti oluşturulurken, amaç maksimizasyon ise ağırlıklandırılmış matris elemanlarının sütun değerlerinden en büyükleri (değerlendirme kriteri minimize etmek için en küçükleri) seçilmektedir. İdeal çözüm seti formül (10)'da verilen eşitlik ile elde edilir. 
Entropi Temelli TOPSIS ve VIKOR Yöntemleri ile Bankacllk Sektöründe Finansal Performans Değerlendirmesi

$\mathrm{A}^{*}=\left\{\left(\max _{i} v_{i j} \mid j \in \mathrm{J}\right),\left(\min _{i} v_{i j} \mid j \in \mathrm{J}^{\prime}\right) i=1,2,3, \ldots, m\right\}=\left\{\mathrm{v}_{1}^{*}, \mathrm{v}_{2}^{*}, \ldots, \mathrm{v}_{\mathrm{n}}^{*}\right\}$

Negatif ideal çözüm setinin bulunuşunda ise, ağırlıklandırılmış matris elemanlarının sütun değerlerinden en küçükleri (değerlendirme kriteri maksimize etmek için en büyükleri) seçilerek oluşturulmaktadır. Negatif ideal çözüm setinin bulunuşu formül (11)'de gösterilmiştir.

$\mathrm{A}^{-}=\left\{\left(\min _{i} v_{i j} \mid j \in \mathrm{J}\right),\left(\max _{i} v_{i j} \mid j \in \mathrm{J}^{\prime}\right) i=1,2,3, \ldots, m\right\}=\left\{\mathrm{v}_{1}^{-}, \mathrm{v}_{2}^{-}, \ldots, \mathrm{v}_{\mathrm{n}}^{-}\right\}$

(10) ve (11) formüllerinde $J$ maksimizasyonu, $J^{\prime}$ ise minimizasyonu ifade eder. $A^{*}$ alternatifi ençok tercih edilen alternatifi veya ideal çözümü, $A^{-}$alternatifi enaz tercih edilen alternatifi veya negatif ideal çözümü içermektedir.

5.Adım: Ayırım Ölçüleri Hesaplanır: İdeal çözüm ve negatif ideal çözüm setinden sapma değerlerinin hesaplanması amacıyla Euclidian Uzaklık yaklaşımı kullanılır. Bulunan değerler ideal ayırım $\left(S_{i}^{*}\right)$ ve negatif ideal ayırım $\left(S_{i}^{-}\right)$ölçüleri olarak tanımlanır. İdeal Uzaklık $\left(\mathrm{S}_{\mathrm{i}}^{*}\right)$ ve Negatif ideal uzaklık $\left(\mathrm{S}_{\mathrm{i}}^{-}\right)$ölçülerinin hesaplaması da aşağıdaki şekilde yapılır.

$\mathrm{S}_{\mathrm{i}}^{*}=\sqrt{\sum_{\mathrm{j}=1}^{\mathrm{n}}\left(v_{i j}-\mathrm{v}_{\mathrm{j}}^{*}\right)^{2}} \quad(12), \quad \mathrm{S}_{\mathrm{i}}^{-}=\sqrt{\sum_{\mathrm{j}=1}^{\mathrm{n}}\left(v_{i j}-\mathrm{v}_{\mathrm{j}}^{-}\right)^{2}}$

$\mathrm{S}_{\mathrm{i}}^{*}$ :Alternatiflerin ideal çözümden Öklid anlayışına göre uzaklığını ifade eder.

$\mathrm{S}_{\mathrm{i}}^{-}$: Alternatiflerin negatif ideal çözümden Öklid anlayışına göre uzaklığını ifade eder.

6.Adım: İdeal Çözüm Elde Edilir: İdeal çözüm değeri formül (14) kullanılarak elde edilir.

$$
\mathrm{C}_{\mathrm{i}}^{*}=\frac{\mathrm{S}_{\mathrm{i}}^{-}}{\mathrm{S}_{\mathrm{i}}^{-}+\mathrm{S}_{\mathrm{i}}^{*}}
$$

$\mathrm{C}_{\mathrm{i}}^{*}, 0 \leq \mathrm{C}_{\mathrm{i}}^{*} \leq 1$ aralığında değer almaktadır. Elde edilen çözüm değerleri sıralanarak ideal çözüm değerleri elde edilir.

\subsection{Vikor Yöntemi}

VIKOR yöntemi birbiriyle çelişen kriterler bulunduğunda, karar vericilerin nihai bir çözüme ulaşmasını sağlamak için, alternatifleri sıralayan ve alternatiflerden uzlaşık çözüm bulmayı sağlayan çok kriterli karar verme yöntemidir. Uzlaşık çözüm değeri, çoğunluk için en yüksek grup fayda değerini ifade ederken ve karşıt görüştekilerin en az pişmanlığını sağlar. Vikor yöntemi ilk olarak Opricovic tarafından ortaya konulmuştur ve çok kriterli optimizasyon ve uzlaşık çözüm şeklinde açıklanır (Dinçer ve Görener, 2011: 248; Yang vd., 2009: 269; Opricovic ve Tzeng, 2007: 515). Uzlaş1k çözüm değeri ideal çözüme en yakın olan uygun çözüm şeklinde ifade edilir (Opricovic ve Tzeng, 2007: 515). Uzlaşık çözümü elde etmek amacıyla ideal çözüme yakınlık derecesi belirlenir 
ve karar verici çoğunluğunun sağlanması için en yüksek grup faydası ve minimum karar verici pişmanlığı sağlanır (Chen \& Wang, 2009: 235).

VIKOR yönteminin çözüm adımları aşağıda anlatılmıştır (Yılmaz, 2012: 33-35; Dinçer ve Görener, 2011: 249):

1.Adım: Karar matrisi, $\left(f_{j}{ }^{*}\right)$ ve $\left(f_{j}^{-}\right)$kriter değerleri belirlenir: Karar probleminin belirlenerek karar matrisine dönüştürüldüğü adımdır.

Karar matrisi belirlendikten sonra değerlendirme kriterleri için en iyi $\left(f_{j}^{*}\right)$ ve en kötü $\left(f_{j}^{-}\right)$değerleri belirlenmektedir.

$\mathrm{j}$ kriteri değerlendirmede "fayda" kriteri olarak alınmış ise, $j=1,2, \ldots, n$ için; $\left(f_{j}^{*}\right)$ ve $\left(f_{j}^{-}\right)$değerleri,

$$
f_{j}^{*}=\max _{i} x_{i j} \quad \text { ve } \quad f_{j}^{-}=\min _{i} x_{i j}
$$

Eğer j kriteri bir maliyet kriteri ise $\left(f_{j}^{*}\right)$ ve $\left(f_{j}^{-}\right)$değerleri,

$$
f_{j}^{*}=\min _{i} x_{i j} \quad \text { ve } \quad f_{j}^{-}=\max _{i} x_{i j}
$$

eşitlikleriyle hesaplanmaktadır.

2.Adım: Normalizasyon İşlemi Yapılır: Karar matrisini oluşturan değerleri karşılaş̧ırabilmek için lineer normalizasyon işlemi yapılır. Karar matrisi, normalizasyon işleminden sonra $m x n$ boyutlu $\mathrm{R}$ matrisine dönüşür. $\mathrm{R}$ matrisinin elemanlar1,

$$
r_{i j}=\frac{f_{j}^{*}-x_{i j}}{f_{j}{ }^{*}-f_{j}{ }^{-}}
$$

formülü kullanılarak bulunur.

3.Adım: Normalize Karar Matrisi Ağırlıklandırılır: Normalize matris elemanlarıyla kriter ağırlıklarının $\left(w_{j}\right)$ çarpılmasıyla $\mathrm{V}$ ağırlıklı matrisine ulaşılır. $v_{i j}$ ağırlıklandırılmış normalize karar matrisinin elemanlarını göstermek üzere, $v_{i j}$

$$
v_{i j}=r_{i j} \cdot w_{j}
$$

eşitliği yardımıyla hesaplanır.

4.Adım: $S_{i}, R_{i}$ ve $Q_{i}$ Değerlerinin Hesaplanması: Burada $w_{i}$, kriter ağırlıklarını göstermektedir. $S_{i}$ ortalama grup değerini, $R_{i}$ ise en kötü grup değerini göstermektedir. $S_{i}$ ve $R_{i}$;

$$
\begin{aligned}
& S_{i}=\sum_{\mathrm{j}=1}^{\mathrm{n}} \frac{w_{j}\left(f_{j}{ }^{*}-x_{i j}\right)}{\left(f_{j}^{*}-f_{j}{ }^{-}\right)} \\
& R_{j}=\max \left[\frac{w_{j}\left(f_{j}{ }^{*}-x_{i j}\right)}{\left(f_{j}{ }^{*}-f_{j}{ }^{-}\right)}\right]
\end{aligned}
$$

formülleriyle hesaplanır. 
Entropi Temelli TOPSIS ve VIKOR Yöntemleri ile Bankacıllk Sektöründe Finansal Performans Değerlendirmesi

Her bir değerlendirme birimi için maksimum grup faydasını ifade eden $Q_{i}$ değerleri hesaplanır.

$$
Q_{i}=\left[\frac{\mathrm{q}\left(S_{i}-\mathrm{S}^{*}\right)}{\left(\mathrm{S}^{-}-\mathrm{S}^{*}\right)}\right]+\left[\frac{(1-\mathrm{q})\left(R_{i}-\mathrm{R}^{*}\right)}{\left(\mathrm{R}^{-}-\mathrm{R}^{*}\right)}\right]
$$

formülündeki $\mathrm{S}^{*}$ minimum $S_{i}$ değerini, $\mathrm{S}^{-}$maksimum $S_{i}$ değerini, $\mathrm{R}^{*}$ değeri minimum $R_{i}$ değerini ve $\mathrm{R}^{-}$maksimum $R_{i}$ değerini ifade eder. q değeri maksimum grup faydası, (1-q) değeri ise karşı görüştekilerin minimum pişmanlığı anlamındadır. Maksimum grup faydası için $\mathrm{q}>0,5$ çoğunluğu, $\mathrm{q}=0,5$ uyuşmayı ve q $<0,5$ reddetmeyi ifade eder. Daha sonra hesaplanan $S_{i}, R_{i}$ ve $Q_{i}$ değerleri küçükten büyüğe doğru sıralanmaktadır.

5.Adım: Ulaşılan sonucun geçerli olup olmadığının belirlenmesi amacıyla $Q_{i}$ değeri için aşağıda verilen iki koşul denetlenir.

1.Koşul: Kabul edilebilirliğe ilişkin avantajlık koşulu: En iyi iki alternatif arasında belirgin bir fark olduğunu ifade eder

$$
\mathrm{Q}\left(A_{2}\right)-\mathrm{Q}\left(A_{1}\right) \geq D Q
$$

Chen ve Wang'a göre; burada $A_{1}$ en iyi Q değerine sahip olan alternatifi, $A_{2}$ ise ikinci siradaki alternatifi ifade etmektedir. Buradan,

$$
D Q=\frac{1}{m-1}
$$

şeklinde hesaplanır. m, değerlendirme birimi sayısını göstermektedir.

2.Koşul: Kabul edilebilirliğe ilişkin istikrarlık koşulu:

$\mathrm{Q}$ değeri en iyi olan $A_{1}$ alternatifinin $\mathrm{S}$ ve $\mathrm{R}$ değerlerinden en az birindeki siralamada en iyi değeri elde etmesi gerekir.

Opricovic ve Tzeng'e göre; Bu koşullardan biri sağlanamadığında uzlaşık çözüm aşağıdaki şekilde ifade edilir:

- 2.Koşul sağlanamadığında $A_{1}$ ve $A_{2}$ alternatiflerinin her ikiside,

- $\quad$ 1.Koşul sağlanamadığında $A_{1}, A_{2}, \ldots \ldots, A_{M}$ alternatiflerinin tümü uzlaşık en iyi ortak çözüm kümesinde yer almaktadır. $\mathrm{Q}\left(A_{\mathrm{M}}\right)$ - $\mathrm{Q}\left(A_{1}\right)<\mathrm{D}(\mathrm{Q})$ eşitsizliğinin dikkate alınmasıyla belirlenir (Dinçer ve Görener, 2011: 249).

Sıralama mantığı açısından her iki grupta bulunan karar noktalarının sıralama sonuçları da istikrarlı karar noktalarını ifade etmektedir.

\section{Uygulama}

\subsection{Veri Seti ve Kullanilan Kriterler}

Çalışmanın uygulama kısmında, Borsa İstanbul (BİST)'da işlemlerini sürdüren 22 bankanın 2009-2018 arası 10 yıllık performansı belirlenmiş olan 26 adet kriter ile incelenmiştir. Tablo-2'de kullanılan kriterler verilmiştir. Analizde 
kullanılan bankaların listesi Tablo-1'de verilmiştir. Çalışmada Türkiye Bankalar Birliğinin veri tabanından elde edilen veriler kullanılmıştır.

Tablo 1. Analize Konu Olan Bankaların Listesi

\begin{tabular}{cc}
\hline Banka İsimleri & \\
\hline Kamu Sermayeli Bankalar & KODLAR \\
\hline T.C. Ziraat Bankası A.Ş. & B22 \\
T.C. Halk Bankası A.Ş. & B11 \\
T.C. Vakıflar Bankası T.A.O. & B20 \\
\hline Özel Sermayeli Bankalar & \\
\hline Adabank A.Ş. & B1 \\
Akbank T.A.Ş. & B2 \\
Anadolubank A.Ş. & B4 \\
Şekerbank T.A.Ş. & B16 \\
Turkish Bank A.Ş. & B17 \\
Türk Ekonomi Bankası A.Ş. & B19 \\
Türkiye İş Bankası A.Ş. & B14 \\
Yapı ve Kredi Bankası A.Ş. & B21 \\
\hline TMSF'ye Devredilen & \\
Bankalar & B6 \\
\hline Birleşik Fon Bankasıı A.Ş. & \\
\hline Yabancı Sermayeli Bankalar & B3 \\
\hline Alternatifbank A.Ş. & B5 \\
Arap Türk Bankası A.Ş. & B7 \\
Citibank A.Ş. & B8 \\
Denizbank A.Ş. & B9 \\
Deutsche Bank A.Ş. & B12 \\
HSBC Bank A.Ş. & B13 \\
ING Bank A.Ş. & B15 \\
QNB Finansbank A.Ş. & B18 \\
Turkland Bank A.Ş. & B10 \\
Türkiye Garanti Bankası A.Ş. & \\
\hline Kaynak: www.tbb.org.tr/tr/bankacilik/banka-ve-sektor-bilgileri/statistiki-raporlar/59 13/10/2019, & \\
\hline www.borsaistanbul.com/borsa uyeleri/uye-bilgileri?g=3 $13 / 10 / 2019$ \\
\hline
\end{tabular}


Entropi Temelli TOPSIS ve VIKOR Yöntemleri ile Bankacllk Sektöründe Finansal Performans Değerlendirmesi

Tablo 2. Analizde Kullanilan Finansal Oranlar, Finansal Oranlartn Performansa Etki Yönleri ve Kriter Kısaltmaları (Kodları)

\begin{tabular}{|c|c|c|}
\hline Kodu & Kriterler (Finansal Oranlar) & Etki \\
\hline \multicolumn{3}{|c|}{ Sermaye Yeterliliği Oranları } \\
\hline S1 & Özkaynaklar /(Kredi+Piyasa+Operasyonel Riske Esas Tutar)'nın oranı & $\max$ \\
\hline S2 & Özkaynaklar / Toplam Aktiflerin oranı & $\max$ \\
\hline S3 & (Özkaynaklar - Duran Aktifler) / Toplam Aktiflerin oranı & $\max$ \\
\hline S4 & Net Bilanço Pozisyonu / Özkaynakların oranı & $\min$ \\
\hline S5 & (Net Bilanço Pozisyonu + Net Nazım Hesap Pozisyonu) / Özkaynakların oranı & $\min$ \\
\hline \multicolumn{3}{|c|}{ Bilanço Yapısı Oranları } \\
\hline BY1 & TP Aktifler / Toplam Aktiflerin oranı & $\max$ \\
\hline BY2 & TP Pasifler / Toplam Pasiflerin oranı & $\max$ \\
\hline BY3 & TP Mevduat / Toplam Mevduatın oranı & $\max$ \\
\hline BY4 & Toplam Mevduat / Toplam Aktiflerin oranı & $\max$ \\
\hline BY5 & Alınan Krediler / Toplam Aktiflerin oranı & $\min$ \\
\hline \multicolumn{3}{|c|}{ Aktif Kalitesi Oranları } \\
\hline A1 & Finansal Varlıklar (net) / Toplam Aktiflerin oranı & $\min$ \\
\hline $\mathrm{A} 2$ & Toplam Krediler ve Alacaklar / Toplam Aktiflerin oranı & $\max$ \\
\hline $\mathrm{A} 3$ & Toplam Krediler ve Alacaklar / Toplam Mevduatın oranı & $\max$ \\
\hline $\mathrm{A} 4$ & Duran Aktifler / Toplam Aktiflerin oranı & $\min$ \\
\hline \multicolumn{3}{|c|}{ Likidite Oranları } \\
\hline L1 & Likit Aktifler / Toplam Aktiflerin oranı & $\max$ \\
\hline $\mathrm{L} 2$ & Likit Aktifler / Kısa Vadeli Yükümlülüklerin oranı & $\max$ \\
\hline $\mathrm{L} 3$ & TP Likit Aktifler / Toplam Aktifler oranı & $\max$ \\
\hline \multicolumn{3}{|c|}{ Karlılık Oranları } \\
\hline K1 & Net Dönem Karı (Zararı) / Toplam Aktiflerin oranı & $\max$ \\
\hline K2 & Net Dönem Karı (Zararı) / Özkaynakların oranı & $\max$ \\
\hline $\mathrm{K} 3$ & Sürdürülen Faaliyetler Vergi Öncesi Kar (Zarar) / Toplam Aktiflerin oranı & $\max$ \\
\hline \multicolumn{3}{|c|}{ Gelir-Gider Yapısı Oranları } \\
\hline G1 & Özel Karşılıklar Sonrası Net Faiz Geliri / Toplam Aktiflerin & $\max$ \\
\hline G2 & Özel Karşılıklar Sonrası Net Faiz Geliri/Toplam Faaliyet Geliri(Gideri)in oranı & $\max$ \\
\hline G3 & Faiz Dışı Gelirler (net) / Toplam Aktiflerin oranı & $\max$ \\
\hline G4 & Diğer Faaliyet Giderleri / Toplam Aktiflerin oranı & $\min$ \\
\hline G5 & Personel Giderleri / Diğer Faaliyet Giderlerin oranı & $\min$ \\
\hline G6 & Faiz D1şı Gelirler (net) / Diğer Faaliyet Giderlerin oranı & $\max$ \\
\hline
\end{tabular}

Kaynak: (Demireli, 2010; Dinçer ve Görener, 2011; Çalışkan ve Eren, 2016; Tezergil, 2016; Yamaltdinova, 2017; Yakut ve Kuru, 2019).

\subsection{Entropi ile Kriter Ağırlıklarının Belirlenmesi}

Karar matrisi oluşturulurken verilerin geometrik ortalaması alınarak, on yıllık veriler her kriter açısından tek değere dönüştürülmüştür. Çünkü geometrik ortalama; uç değerlerden aritmetik ortalama kadar etkilenmemektedir. Verilerdeki anlık ve normal olmayan artışlara karşı aritmetik ortalama kadar duyarlı değildir. Ayrıca literatürde genellikle geometrik ortalama kullanılmıştır. Geometrik ortalamaya uygun olmayan verilerin olduğu kriterlerde tüm alternatiflerin ilgili kriter değerlerine aynı değer eklenerek geometrik ortalamaya uygun hale getirilmiştir. Fayda ve maliyet kriterlerinin hesaplanabilmesi için karar matrisinin fayda ve maliyet kriterleri dikkate alınarak normalizasyon işlemi 
(1), (2) ve (3) eşitlikleri kullanılarak elde edilmiştir. Normalize edilmiş karar matrisi $\left(P_{i j}\right.$ Matrisi), ilgili alternatiflerin kriter değerlerinin ilgili kriter değerinin toplamına bölünmesiyle oluşturulmuştur. Ardından entropi değerleri hesaplanmıştır. Öncelikle $P_{i j} \cdot \ln \left(P_{i j}\right)$ değeri hesaplanmıştır. Bu aşamada her bir kriterin $\left(P_{i j}\right)$ logaritmas1 $\left(\ln \left(P_{i j}\right)\right)$ hesaplanmış, hesaplanan logaritma değerleriyle kriter değerleri çarpılarak $P_{i j} \cdot \ln \left(P_{i j}\right)$ değerleri elde edilmiştir. Entropi değerinin hesaplanmasında; $\mathrm{k}$ entropi katsayıs1, banka sayısı 22 olduğundan $\mathrm{m}=22$ için,

$\ln (22)=3,091042453$ ve $k=(\ln (m))^{-1}=0,323515453$ elde edilmiş ve (4) formülü yardımıyla entropi değerleri hesaplanmıştır. Daha sonra tüm kriterler için eşitlik (6) yardımıyla $D_{j}$ değerleri hesaplanmıştır. $D_{j}$ değerleri, $D_{j}=1-e_{j}$ eşitliği ile hesaplanır. Kriter ağırlıkları hesaplanırken ise eşitlik (7) yardımıyla ilgili kriterin $D_{j}$ değeri toplam $D_{j}$ değerine bölünür. Tablo-3'te karar matrisinin oluşturulması için belirlenen değerler, Tablo-4'te kriter ağırlıkları gösterilmiştir.

Tablo 3. Entropi Yöntemi Karar Matrisi Verileri

\begin{tabular}{ccccccc}
\hline BANKA & S1 & S2 & S3 & S4 & S5 & BY1 \\
\hline B1 & 187,742124 & 86,817973 & 81,642168 & 204,253593 & 18,249851 & 99,582115 \\
B2 & 17,104445 & 12,956289 & 11,335312 & 163,185332 & 18,976936 & 60,442326 \\
B3 & 15,35532 & 8,049686 & 4,970656 & 155,424828 & 20,404995 & 62,373898 \\
B4 & 16,535329 & 14,43236 & 10,360576 & 185,288351 & 12,435707 & 72,433116 \\
B5 & 20,386297 & 16,155339 & 13,046458 & 194,200359 & 18,031182 & 27,339035 \\
B6 & 58,195458 & 42,268978 & 38,730888 & 208,410023 & 21,271443 & 73,711304 \\
B7 & 19,944667 & 15,550927 & 15,035873 & 141,807112 & 14,896583 & 79,567781 \\
B8 & 16,369909 & 10,357998 & 4,722534 & 105,649528 & 19,351532 & 69,439015 \\
B9 & 31,00857 & 18,975998 & 17,430704 & 91,184272 & 25,055803 & 71,44326 \\
B10 & 17,255318 & 12,479941 & 9,420776 & 185,32019 & 19,215872 & 60,618114 \\
B11 & 14,446484 & 9,626137 & 6,760441 & 191,866817 & 16,245214 & 67,59301 \\
B12 & 16,987939 & 10,750442 & 8,487774 & 76,477268 & 16,21056 & 67,242832 \\
B13 & 15,860383 & 10,963958 & 8,784216 & 88,714675 & 18,18083 & 73,835989 \\
B14 & 16,013584 & 11,923135 & 6,403684 & 174,479201 & 13,265955 & 63,592509 \\
B15 & 16,452745 & 11,329289 & 8,137461 & 78,491345 & 7,392703 & 76,099574 \\
B16 & 14,313824 & 10,698559 & 4,551846 & 133,930467 & 17,608772 & 78,639239 \\
B17 & 21,615381 & 14,701794 & 10,406428 & 180,562519 & 16,738069 & 57,568711 \\
B18 & 15,799592 & 13,907463 & 11,033887 & 204,461884 & 18,209364 & 76,321588 \\
B19 & 15,063637 & 10,167426 & 7,914601 & 130,106067 & 18,485236 & 73,498493 \\
B20 & 14,77431 & 9,816197 & 7,22343 & 203,301298 & 22,82084 & 65,921123 \\
B21 & 15,408978 & 11,335069 & 6,628205 & 163,843651 & 18,317398 & 60,567185 \\
B22 & 16,582306 & 9,831701 & 7,704307 & 195,328439 & 18,348437 & 73,121471 \\
\hline & & & & & &
\end{tabular}


Entropi Temelli TOPSIS ve VIKOR Yöntemleri ile Bankacıllk Sektöründe Finansal Performans Değerlendirmesi

Tablo 3 Devamı: Entropi Yöntemi Karar Matrisi Verileri

\begin{tabular}{ccccccc}
\hline BANKA & BY2 & BY3 & BY4 & BY5 & A1 & A2 \\
\hline B1 & 99,797103 & 53,610561 & 5,702155 & 1 & 2,894094 & 1 \\
B2 & 53,822012 & 54,51405 & 57,681712 & 11,137949 & 30,838463 & 56,183783 \\
B3 & 50,322478 & 59,064918 & 55,199173 & 17,174932 & 16,119525 & 69,529046 \\
B4 & 64,05346 & 63,438121 & 67,645096 & 5,408084 & 14,00561 & 67,800142 \\
B5 & 23,34005 & 3,960643 & 56,246401 & 7,878735 & 19,222391 & 35,547341 \\
B6 & 74,948471 & 43,194207 & 3,562353 & 1 & 40,401187 & 5,531403 \\
B7 & 65,19818 & 59,799022 & 71,235539 & 5,260247 & 18,273675 & 40,543062 \\
B8 & 56,401217 & 60,496868 & 58,933269 & 14,959851 & 16,364818 & 64,343885 \\
B9 & 59,478937 & 57,43066 & 28,119511 & 37,710173 & 29,932305 & 27,110946 \\
B10 & 56,060533 & 52,907856 & 56,75539 & 14,066519 & 23,671833 & 59,746704 \\
B11 & 66,14674 & 64,65085 & 69,060961 & 7,383261 & 22,432318 & 64,018505 \\
B12 & 50,874017 & 47,10292 & 60,137227 & 15,807896 & 13,663806 & 58,616937 \\
B13 & 57,341382 & 71,399362 & 53,543775 & 26,344631 & 13,241597 & 72,662171 \\
B14 & 58,243494 & 54,891286 & 59,206703 & 9,395665 & 23,410894 & 60,24119 \\
B15 & 59,74216 & 62,989776 & 58,803914 & 8,576623 & 21,150477 & 65,274563 \\
B16 & 67,409441 & 64,642 & 67,007017 & 7,108162 & 17,662935 & 66,696088 \\
B17 & 51,346036 & 40,172363 & 64,899333 & 11,166613 & 7,733117 & 49,884648 \\
B18 & 67,381315 & 60,648868 & 73,229735 & 4,668228 & 17,608875 & 64,275537 \\
B19 & 62,394419 & 64,718583 & 63,342316 & 15,344404 & 13,386848 & 69,327408 \\
B20 & 64,221385 & 69,997879 & 61,234201 & 10,259345 & 19,158874 & 65,395644 \\
B21 & 53,175708 & 54,157105 & 58,910485 & 11,689575 & 18,661298 & 64,850938 \\
B22 & 72,014272 & 70,129791 & 67,877193 & 3,685946 & 31,752538 & 52,388478 \\
\hline
\end{tabular}

Tablo 3 Devamı: Entropi Yöntemi Karar Matrisi Verileri

\begin{tabular}{ccccccl}
\hline BANKA & $\mathbf{A 3}$ & $\mathbf{A 4}$ & $\mathbf{L 1}$ & $\mathbf{L 2}$ & $\mathbf{L 3}$ & $\mathbf{K 1}$ \\
\hline B1 & 1 & 5,07534 & 94,389265 & 1308,620577 & 93,970054 & 8,617214 \\
B2 & 96,665234 & 1,501758 & 32,529297 & 60,745319 & 13,895673 & 8,877125 \\
B3 & 125,148763 & 3,033862 & 18,131553 & 36,823106 & 6,989928 & 7,744897 \\
B4 & 99,751933 & 3,757264 & 21,261469 & 42,944316 & 6,060116 & 8,83534 \\
B5 & 62,528435 & 3,053299 & 49,487337 & 105,632815 & 3,156719 & 8,827258 \\
B6 & 64,381154 & 3,509621 & 42,920284 & 861,093876 & 28,741687 & 9,93846 \\
B7 & 56,498937 & 0,439479 & 55,326471 & 77,210911 & 46,218143 & 8,809797 \\
B8 & 108,485292 & 5,094599 & 25,156338 & 46,343042 & 11,379217 & 8,539218 \\
B9 & 92,771466 & 0,916311 & 58,307014 & 108,178083 & 44,882905 & 9,448342 \\
B10 & 104,507443 & 3,008798 & 28,267148 & 51,638926 & 11,848784 & 8,922123 \\
B11 & 92,254624 & 2,857285 & 18,836799 & 32,012589 & 7,077583 & 8,768874 \\
B12 & 96,815652 & 2,151162 & 37,92793381 & 67,267209 & 18,948607 & 7,262926 \\
B13 & 134,840492 & 2,132041 & 23,279903 & 43,311803 & 12,031897 & 7,901649 \\
B14 & 101,060736 & 5,505385 & 26,082143 & 46,568876 & 11,834764 & 8,679429 \\
B15 & 110,306528 & 3,105223 & 24,069901 & 46,190407 & 10,669923 & 8,533479 \\
B16 & 99,045483 & 5,550946 & 19,661213 & 33,985784 & 10,68124 & 7,950417 \\
B17 & 76,246565 & 4,248451 & 38,577244 & 68,437866 & 13,597131 & 7,243164 \\
B18 & 87,408536 & 2,559189 & 28,732028 & 50,553104 & 14,753724 & 5,805527 \\
B19 & 108,86905 & 2,160079 & 25,444833 & 41,790155 & 11,865255 & 8,110476 \\
B20 & 106,168176 & 2,572736 & 24,358969 & 44,795054 & 10,048877 & 8,380505 \\
B21 & 109,386979 & 4,600354 & 21,116681 & 39,083378 & 9,678979 & 8,554489 \\
B22 & 76,726748 & 2,045748 & 28,796331 & 43,782269 & 14,842027 & 8,86844 \\
\hline & & & & & & \\
\hline
\end{tabular}


Tablo 3 Devamı: Entropi Yöntemi Karar Matrisi Verileri

\begin{tabular}{ccccc}
\hline BANKA & K2 & $\mathbf{K 3}$ & $\mathbf{G 1}$ & $\mathbf{G 2}$ \\
\hline B1 & 53,103424 & 9,849917 & 13,855865 & 184,418384 \\
B2 & 65,474262 & 10,306907 & 6,815914 & 148,06458 \\
B3 & 60,055473 & 8,878533 & 6,375227 & 137,722518 \\
B4 & 63,370863 & 10,251172 & 7,799449 & 152,384174 \\
B5 & 62,288569 & 10,171226 & 6,967456 & 156,786442 \\
B6 & 58,396124 & 11,456994 & 7,8846 & 148,62221 \\
B7 & 63,094757 & 10,237376 & 9,460247 & 166,814671 \\
B8 & 65,415457 & 9,705613 & 7,345137 & 148,057608 \\
B9 & 63,262702 & 11,143013 & 9,883372 & 179,152364 \\
B10 & 66,445348 & 10,389833 & 7,143423 & 149,092958 \\
B11 & 68,759233 & 10,16708 & 6,957131 & 155,151916 \\
B12 & 51,725218 & 8,488653 & 7,397657 & 145,445846 \\
B13 & 59,120064 & 9,137765 & 8,237847 & 165,946187 \\
B14 & 65,100075 & 9,986836 & 6,813281 & 148,475411 \\
B15 & 64,412042 & 9,80297 & 7,900316 & 154,917863 \\
B16 & 59,261482 & 9,145769 & 7,41844 & 144,621581 \\
B17 & 52,69956 & 8,259517 & 6,934076 & 169,930221 \\
B18 & 33,896438 & 6,411578 & 4,758044 & 85,600001 \\
B19 & 62,051391 & 9,311903 & 7,433079 & 155,073913 \\
B20 & 64,916185 & 9,666658 & 6,599999 & 145,703188 \\
B21 & 64,501012 & 9,803146 & 6,506775 & 140,030117 \\
B22 & 70,1109601 & 10,285412 & 7,468749 & 168,647909 \\
\hline
\end{tabular}

Tablo 3 Devamı: Entropi Yöntemi Karar Matrisi Verileri

\begin{tabular}{cllll}
\hline BANKA & \multicolumn{1}{c}{ G3 } & \multicolumn{1}{c}{ G4 } & \multicolumn{1}{c}{ G5 } & G6 \\
\hline B1 & 5,907324 & 8,363202 & 42,865685 & 171,108865 \\
B2 & 6,554352 & 1,733038 & 40,699518 & 249,064298 \\
B3 & 6,343293 & 2,261244 & 54,283171 & 223,074889 \\
B4 & 6,57369 & 2,695212 & 71,048096 & 224,709387 \\
B5 & 6,487029 & 1,664558 & 76,164893 & 252,168036 \\
B6 & 8,263068 & 2,204518 & 59,907382 & 275,076364 \\
B7 & 6,489888 & 4,404811 & 36,592898 & 191,595729 \\
B8 & 6,403389 & 2,807235 & 48,819205 & 210,589485 \\
B9 & 4,405858 & 3,678982 & 31,550686 & 104,450178 \\
B10 & 6,694891 & 2,097081 & 41,954992 & 240,725883 \\
B11 & 6,280961 & 1,700599 & 46,155573 & 234,5383 \\
B12 & 6,795955 & 4,178881 & 46,024419 & 201,181836 \\
B13 & 5,640879 & 3,342026 & 44,085811 & 183,062546 \\
B14 & 6,654321 & 2,121009 & 49,006572 & 234,456126 \\
B15 & 6,261867 & 2,914111 & 43,834564 & 201,602223 \\
B16 & 6,812865 & 3,660715 & 43,60158 & 208,316551 \\
B17 & 5,691285 & 3,034015 & 54,5257888 & 182,777518 \\
B18 & 6,578357 & 3,671895 & 50,613696 & 200,918156 \\
B19 & 6,391476 & 3,106302 & 46,757857 & 204,05442 \\
B20 & 6,427638 & 1,904357 & 41,951713 & 235,648118 \\
B21 & 6,86275 & 2,19033 & 43,478318 & 242,528541 \\
B22 & 5,748164 & 1,516787 & 47,632085 & 206,893223 \\
\hline
\end{tabular}


Entropi Temelli TOPSIS ve VIKOR Yöntemleri ile Bankacıllk Sektöründe Finansal Performans Değerlendirmesi

Tablo 4. Entropi $\left(E_{j}\right)$ Değerleri, $\left(D_{j}\right)$ Değerleri ve Kriter A $\breve{g}$ ırlıkları $\left(W_{j}\right)$

\begin{tabular}{cccc}
\hline KRİTERLER & $\boldsymbol{E}_{\boldsymbol{j}}$ & $\boldsymbol{D}_{\boldsymbol{j}}$ & $\boldsymbol{W}_{\boldsymbol{j}}$ \\
\hline S1 & 0,856607068 & 0,143392932 & 0,102367035 \\
$\mathbf{S 2}$ & 0,908570908 & 0,091429092 & 0,065270477 \\
$\mathbf{S 3}$ & 0,868074598 & 0,131925402 & 0,09418046 \\
S4 & 0,980141745 & 0,019858255 & 0,014176645 \\
S5 & 0,987160456 & 0,012839544 & 0,009166045 \\
BY1 & 0,993913696 & 0,006086304 & 0,004344962 \\
BY2 & 0,991900631 & 0,008099369 & 0,005782073 \\
BY3 & 0,98553177 & 0,01446823 & 0,010328751 \\
BY4 & 0,973627487 & 0,026372513 & 0,01882712 \\
BY5 & 0,817305324 & 0,182694676 & 0,130424227 \\
A1 & 0,917158442 & 0,082841558 & 0,059139907 \\
A2 & 0,968359843 & 0,031640157 & 0,022587648 \\
A3 & 0,978997988 & 0,021002012 & 0,014993164 \\
A4 & 0,906258992 & 0,093741008 & 0,066920935 \\
L1 & 0,964738255 & 0,035261745 & 0,02517307 \\
L2 & 0,66731012 & 0,33268988 & 0,23750457 \\
L3 & 0,882307815 & 0,117692185 & 0,084019483 \\
K1 & 0,998315841 & 0,001684159 & 0,001202307 \\
K2 & 0,997233124 & 0,002766876 & 0,00197525 \\
K3 & 0,998065624 & 0,001934376 & 0,001380935 \\
G1 & 0,992886941 & 0,007113059 & 0,005077954 \\
G2 & 0,997296626 & 0,002703374 & 0,001929916 \\
G3 & 0,998151003 & 0,001848997 & 0,001319984 \\
G4 & 0,979508853 & 0,020491147 & 0,014628461 \\
G5 & 0,994473388 & 0,005526612 & 0,003945403 \\
G6 & 0,995330922 & 0,004669078 & 0,003333216 \\
TOPLAM & & 1,40077254 & \\
\hline
\end{tabular}

\subsection{Topsis Yöntemi Uygulaması}

Karar matrisi verileri, Entropi hesaplamasında tablo-3'te verilmiştir. Normalizasyon işlemi için karar matrisinde verilen her bir verinin kareleri alınır. Her bir kriterin oluşan kare değerleri toplanarak karekökü hesaplanır. Karar matrisinin (tablo-3) her bir elemanının hesaplanan karekök değerine bölünmesi ile karar matrisi normalize edilmiştir. Ağırlıklandırılmış normalize matrisin elde edilmesinde, Entropi yöntemiyle hesaplanmış olan kriter ağırlıkları normalize matrisin ilgili kriter değerleri ile çarpılmıştır. Pozitif $\left(S_{i}^{*}\right)$ ve negatif $\left(S_{i}^{-}\right)$ideal çözümlerin elde edilmesi işlemi, formül (12) ve (13) kullanılarak ayrı ayrı yapılmıştır.

Pozitif $\left(S_{i}^{*}\right)$ ve negatif $\left(S_{i}^{-}\right)$ideal çözümlerin elde edilmesinden sonra,

$$
C_{i}^{*}=\frac{S_{i}^{-}}{S_{i}^{*}+S_{i}^{-}}
$$

formülü kullanılarak ideal çözüm değeri hesaplanmıştır. 
Tablo 5. TOPSIS Yöntemine ait Pozitif İdeal $\left(S_{i}^{*}\right)$ Çözüm, Negatif İdeal ( $\left.S_{i}^{-}\right)$ Çözüm, İdeal Çözüm Değerleri ve Banka Stralamalar

\begin{tabular}{clccc}
\hline SIRALAMA & BANKA & $S_{i}^{*}$ & $S_{i}^{-}$ & IDEAL ÇÖZÜM \\
\hline $\mathbf{1}$ & ADABANK & 0,025513756 & 0,245940229 & 0,906010752 \\
$\mathbf{1 2}$ & AKBANK & 0,226834354 & 0,059131545 & 0,206778309 \\
$\mathbf{2 0}$ & ALTERNATIFBANK & 0,23471939 & 0,047135924 & 0,16723447 \\
$\mathbf{6}$ & ANADOLUBANK & 0,22968139 & 0,069068965 & 0,231192912 \\
$\mathbf{7}$ & ARAPTÜRK BANK & 0,220993893 & 0,065632084 & 0,228981632 \\
$\mathbf{2}$ & BİRLEŞİK FON B. & 0,115467923 & 0,152476642 & 0,569060402 \\
$\mathbf{3}$ & CITIBANK & 0,217605494 & 0,078027382 & 0,263933372 \\
$\mathbf{1 9}$ & DENIZBANK & 0,232439642 & 0,050342537 & 0,178025848 \\
$\mathbf{2 1}$ & DEUTSCHE BANK & 0,223563548 & 0,041965971 & 0,158046348 \\
$\mathbf{1 7}$ & GARANTİ & 0,229390589 & 0,052351983 & 0,185814955 \\
$\mathbf{8}$ & HALKBANK & 0,232963695 & 0,064695106 & 0,217346524 \\
$\mathbf{1 6}$ & HSBC BANK & 0,22691343 & 0,052391801 & 0,187579017 \\
$\mathbf{2 2}$ & ING BANK & 0,234689845 & 0,035105358 & 0,130118541 \\
$\mathbf{1 4}$ & İŞ BANKASI & 0,23098766 & 0,05989471 & 0,205906979 \\
$\mathbf{1 0}$ & QNB FINANS B. & 0,229836996 & 0,062491912 & 0,213772605 \\
$\mathbf{9}$ & SSEKERBANK & 0,233288687 & 0,064718142 & 0,217169996 \\
$\mathbf{1 1}$ & TURKISH BANK & 0,22511779 & 0,059991004 & 0,210414428 \\
$\mathbf{5}$ & TURKLAND BANK & 0,227098104 & 0,071183956 & 0,238646454 \\
$\mathbf{1 8}$ & TÜRK EKONOMİ B. & 0,231588111 & 0,052225018 & 0,184011987 \\
$\mathbf{1 3}$ & VAKIFBANK & 0,230939841 & 0,059956862 & 0,206110489 \\
$\mathbf{1 5}$ & YAPI KREDİ B. & 0,232313263 & 0,056058914 & 0,19439779 \\
$\mathbf{4}$ & ZİRAAT BANKASI & 0,229515528 & 0,072187201 & 0,239265987 \\
\hline
\end{tabular}

İdeal çözüm değerlerine bakıldığında en yüksek performans değerini Adabank'ın aldığı sonucuna ulaşılmıştır. İkinci, üçüncü ve dördüncü sıralarda ise Birleşik Fon Bankası, Citibank ve Ziraat Bankası sıralanmıştır.

\subsection{Vikor Yöntemi Uygulaması}

Karar matrisini oluşturan değerler Entropi yönteminde verilmiştir. Burada her kriterin en iyi $f_{j}^{*}$ ve en kötü $f_{j}^{-}$değerleri karar matrisi kullanılarak hesaplanmıştır. Burada $f_{j}^{*}$ değerleri belirlenirken maksimum (fayda) kriterler için ilgili sütunun en yüksek değeri alınırken, minimum (maliyet) kriterler için ilgili sütunun en küçük değeri alınmıştır. Yine $f_{j}^{-}$değerleri belirlenirken maksimum (fayda) kriterler için ilgili sütunun en küçük değeri alınırken, minimum (maliyet) kriterler için ilgili sütunun en büyük değeri alınmıştır. Karar matrisinin normalize edilmesinde, $\frac{f_{j}^{*}-x_{i j}}{f_{j}^{*}-f_{j}^{-}}$formülünden yararlanılmıştır. Karar matrisinin normalize edilmesinden sonra Entropi yöntemiyle hesaplanmış olan kriter ağırlıkları kullanılarak, ilgili kriter değerleri ile ilgili kriter ağırlığı çarpılmış ve ağırlıklandırılmış normalize matris oluşturulmuştur.

Daha sonra $S_{i}$ değeri, ağırlıklandırılmış normalize matrisin her bir satır elemanları toplanarak elde edilmiştir. $R_{i}, Q_{i}, S^{*}, S^{-}, R^{*}$ ve $R^{-}$değerleri (19), (20) ve (21) eşitlikleri kullanılarak hesaplanmıştır. $R_{i}$ değerleri ağılıklandırılmış matrisin her satırının maksimum elemanı alınarak elde edilmiştir. $S^{*}, S_{i}$ 
Entropi Temelli TOPSIS ve VIKOR Yöntemleri ile Bankacllk Sektöründe Finansal Performans Değerlendirmesi

değerlerinin minimum değerinden oluşurken, $S^{-}$değeri ise $S_{i}$ değerlerinin maksimum değerinden oluşur. $R^{*}, R_{i}$ değerlerinin minimum değerinden oluşurken, $R^{-}$değeri ise $R_{i}$ değerlerinin maksimum değerinden oluşmaktadır.

$Q_{i}$ değerleri formül (21) kullanılarak hesaplanmıştır. Burada $Q_{i}$ değerleri, $q=0,5$ parametresine göre konsensus (uzlaşma) değeri için hesaplanmıştır.

Her bir alternatif için $Q_{i}$ değerleri hesaplanmış ve ardından bu değerlere göre tüm alternatiflerin sıralaması yapılmıştır. Yapılmış olan bu sıralamanın doğruluğunu sinamak amaciyla minimum $Q_{i}$ değerine sahip alternatifin ' $1 . K o s ̧ u l$ ' ve '2.koşul'u sağlayıp sağlamadığına bakılır. Öncelikle eşitlik (23) yardımıyla $D Q$ değeri hesaplanır.

$$
D Q=\frac{1}{22-1}=0,047619048
$$

1.Koşul: $Q_{i}$ değerlerinin küçükten büyüğe sıralandığında ilk siradaki $A^{1}$ alternatifi ile ikinci siradaki $A^{2}$ alternatifi arasında,

$$
Q\left(A^{2}\right)-Q\left(A^{1}\right) \geq D Q, \quad 0,356278931-0 \geq 0,047619048
$$

olduğundan koşul-1 sağlanmaktadır.

2.Koşul: $Q_{i}$ değerleri incelendiğinde ilk sıradaki alternatif $S_{i}$ ve $R_{i}$ değerlerinde de minimum değeri aldığından en iyi seçenek olmaktadır.

$Q_{i}$ değerleri için '1.Koşul' ve '2.Koşul'un sağlandığı görülmektedir. $Q_{i}$ değerlerine göre yapılan sıralama uzlaşık çözüm olarak önerilebilir. Uzlaşık çözüme göre en iyi alternatifin ADABANK olduğu sonucuna ulaşılmıştır.

\begin{tabular}{|c|c|c|c|c|c|c|}
\hline & $S_{i}$ & $\begin{array}{c}S_{i} \\
\text { SIRA }\end{array}$ & $\boldsymbol{R}_{\boldsymbol{i}}$ & $\begin{array}{c}R_{i} \\
\text { SIRA }\end{array}$ & $Q_{i}$ & $\begin{array}{c}Q_{i} \\
\text { SIRA }\end{array}$ \\
\hline ADABANK & 0,158830652 & 1 & 0,060694152 & 1 & 0 & 1 \\
\hline AKBANK & 0,713766096 & 9 & 0,232159033 & 8 & 0,945219488 & 7 \\
\hline ALTERNATİFBANK & 0,757537126 & 20 & 0,236609605 & 20 & 0,994114623 & 22 \\
\hline ANADOLUBANK & 0,705118375 & 5 & 0,235470794 & 17 & 0,947411223 & 10 \\
\hline ARAPTÜRK BANK & 0,722012377 & 12 & 0,223808008 & 4 & 0,928444271 & 4 \\
\hline BİRLEŞİK FON B. & 0,511399698 & 2 & 0,083259417 & 2 & 0,356278931 & 2 \\
\hline CITIBANK & 0,613672203 & 3 & 0,229095718 & 5 & 0,853525804 & 3 \\
\hline DENIZBANK & 0,761580997 & 22 & 0,234838483 & 12 & 0,992460605 & 21 \\
\hline DEUTSCHE BANK & 0,748219564 & 18 & 0,223334478 & 3 & 0,948844851 & 12 \\
\hline GARANTİ & 0,741770261 & 15 & 0,233853218 & 9 & 0,973240771 & 16 \\
\hline HALKBANK & 0,725172836 & 14 & 0,23750457 & 22 & 0,969798308 & 15 \\
\hline HSBC BANK & 0,706226481 & 8 & 0,230945678 & 7 & 0,935533913 & 6 \\
\hline ING BANK & 0,746542652 & 16 & 0,235402425 & 16 & 0,981580599 & 17 \\
\hline İŞ BANKASI & 0,759937259 & 21 & 0,234796468 & 11 & 0,99097826 & 20 \\
\hline QNB FINANS B. & 0,705396325 & 6 & 0,23486688 & 13 & 0,94593399 & 8 \\
\hline ŞEKERBANK & 0,747806398 & 17 & 0,23713747 & 21 & 0,987535428 & 18 \\
\hline TURKISH BANK & 0,719687741 & 11 & 0,230727885 & 6 & 0,946084549 & 9 \\
\hline TURKLAND BANK & 0,693874777 & 4 & 0,234055228 & 10 & 0,934081252 & 5 \\
\hline TÜRK EKONOMİ B. & 0,716010808 & 10 & 0,235685518 & 18 & 0,957054048 & 13 \\
\hline VAKIFBANK & 0,723663339 & 13 & 0,235126476 & 14 & 0,961821151 & 14 \\
\hline YAPI KREDİ B. & 0,754081335 & 19 & 0,236189096 & 19 & 0,990058786 & 19 \\
\hline ZIRAAT BANKASI & 0,706211961 & 7 & 0,235314898 & 15 & 0,947877531 & 11 \\
\hline
\end{tabular}

Tablo 6. VIKOR Yöntemi $S_{i}, R_{i}, Q_{i}$ Değerleri ve Stralamaları 


\section{Sonuç}

Çok kriterli karar verme problemlerinde birçok faktör aynı anda etkili olabilmektedir. Kriterlerin önem ağırlıklarının belirlenmesinde subjektif veya objektif yöntemler kullanılabilmektedir. Kriter ağırlıklarının hesaplanmasında literatürde en yaygın olarak kullanılan yöntemlerden biri uzman görüşlerine yer verilen AHP yöntemidir. Ancak AHP subjektif bir yöntemdir. Bu çalışmada kriterlerin önem ağıllıkları belirlenirken, subjektif yargılara yer vermemek amacıyla entropi yöntemi kullanılmıştır.

Entropi yönteminde; "Likit Aktifler / Kısa Vadeli Yükümlülükler" oranı en yüksek değeri alan kriter olarak elde edilirken, "Alınan Krediler / Toplam Aktifler" oranı ikinci sırada ve "Özkaynaklar / (Kredi + Piyasa + Operasyonel Riske Esas Tutar)" üçüncü sıradaki kriterler olarak öne çıkmaktadır. Sermaye yeterliliği ve likidite oranlarının entropi ağırlığının diğer oranlara göre yüksek değerler aldığı görülmüştür.

$\mathrm{Bu}$ çalışmada öne çıkan kriterlerin ağırlık değerleri ile literatürdeki bazı çalışmaların sonuçlarının tutarlılık gösterdiği ve destekleyici olduğu görülmektedir. Örneğin; Akgül (2019)'ün çalışmasında da Entropi yöntemi sonuçlarına göre en önemli görülen üç performans kriteri sıra ile, "Likit Aktifler/Kısa Vadeli Yükümlülükler", "Duran Varlıklar/Toplam Varlıklar" ve "Alınan Krediler/Toplam Varlıklar" olarak elde edilmiştir. Altunöz (2017), belirlenen kriterlerin önem ağırlıklarına göre; karlılık, sermaye, bilanço ve likidite oranları yüksek olan bankaların, finansal performanslarının da yüksek olacağı ifade edilirken, aktif kalite oranları ve gelir-gider yapısı oranlarının banka performansı belirlerken etkisinin daha düşük olduğunu belirtmiştir. Dinçer ve Görener (2011)'in yaptığı çalışmada, hesaplanan kriter ağırlıklarına göre Sermaye yeterliliği ve Likidite oranlarının öne çıktı̆̆ görülmüştür.

"Likit Aktifler/Kısa Vadeli Yükümlülükler" finansal oranı, bir bankanın likit aktifleri ile yakın vadedeki yükümlülüklerinin ne kadarını karşılayabileceğini gösterir. Bu değerin maksimum seviyede olması banka için sorumlulukların yerine getirilmesinde ve oluşabilecek bir kriz durumunda kısa vadeli olan ödemelerinde problem olmayacağını göstermektedir. Likidite oranları genel olarak bankalar için kısa vadeli yükümlülüklerini yani ödeme gücünü ifade eder. Kaynakların ne kadarının likit olduğu bankalar için dikkate alınması gereken bir konudur. Sermaye yeterliliği bankaların paydaşlarını korumak ve güvenlerini kazanmak için önemli bir kavramdır. Bankalar kriz zamanlarında ya da dönem dönem beklenmeyen zararlarla karşılaşabilmektedirler. Sermaye yeterliliği, bu zararların doğuracağı sıkıntıları gidermek için bankaların yeterli gücünün olup olmadığını ifade eder.

ÇKKV yöntemlerinin farklı hesaplama teknikleri olduğundan, sıralamalarda farklı sonuçlar ortaya çıkabilmektedir. VIKOR yöntemi, ideal alternatife yakınlığa göre karşılaştırarak alternatifler arasında sıralama yapmaktadır. Topsis yöntemi ise pozitif ideal çözüm değerine yakınlık ve negatif ideal çözüm değerine uzaklığa göre sıralama yapmaktadır. Çalışmada elde edilen 
Entropi Temelli TOPSIS ve VIKOR Yöntemleri ile Bankacllk Sektöründe Finansal Performans Değerlendirmesi

alternatiflerin sıralama sonuçları incelendiğinde; Topsis yöntemi ve VIKOR yöntemlerinin her ikisinde de ilk sırayı Adabank, ikinci sırayı Birleşik Fon Bankası ve üçüncü sırayı CITIBANK almıştır. Bu üç bankanın diğer bankalara göre daha iyi performans sergilediği söylenebilir. TOPSIS yönteminde dördüncü sırayı Ziraat Bankası alırken, VIKOR yönteminde dördüncü sırayı ARAPTÜRK bankasının aldığı görülmüştür. TOPSIS yönteminde son iki sırayı DEUTSCHE Bank ve ING Bank alırken, VIKOR yönteminde ise Alternatifbank ve Denizbank almıştır. Diğer banka sıralamaları incelendiğinde de yöntemlere göre sıralamalarda değişiklikler olmuştur. $\mathrm{Bu}$ çalışmada elde edilen analiz sonuçlarının literatürde yapılmış olan çalışmalara benzer sonuçlar verdiği ifade edilebilir. Örneğin; Gazel (2019) ve Özel (2016)'in çalışmalarında elde edilen sonuçlara göre de performansı en yüksek bankanın ADABANK olduğu ifade edilmiştir. Yine öne çıkan bankalar bu çalışma ile benzerlik göstermektedir.

\section{Öneriler}

En önemli kriter olarak öne çıkan "Likit Aktifler / Kısa Vadeli Yükümlülükler" oranı, bankalar bazında incelendiğinde alt sıralarda kalan bankalarda bu oranın düşük olduğu gözlemlenmiştir. "Likit Aktifler / Kısa Vadeli Yükümlülükler” oranı düşük olan bankaların bu oranı yüksek tutacak çalışmalar yapmaları, muhtemel bir kriz durumunda ödeme güçlüğü çekmemeleri anlamında faydalı olacaktır.

“Alınan Krediler / Toplam Aktifler" oranı da öne çıkan kriterlerden biridir. $\mathrm{Bu}$ kriterinde bankalar açısından minimum düzeyde tutulması yararlı olacaktır.

Yine elde edilen kriter ağırlı̆̆ı sonuçlarına göre, "Sermaye Yeterliliğ̣i" oranlarının iyi seviyede olmasının bankalar açısından önemli olduğu ifade edilebilir.

Bankaların öne çıkan maksimum yönlü kriterler ile ilgili banka yapısını güçlendirici ve öne çıkan minimum yönlü kriterler ile ilgili de düşük seviyede tutacak çalışmalar yapmaları önerilebilir. Örneğin; Alternatifbank, Denizbank, Şekerbank, Yapı-Kredi Bankası, ING Bank ve İş Bankası gibi performans değerlendirme sonuçlarına göre, alt ve orta sıralarda yer alan bankaların bu bağlamda değerlendirme yapmalarının yararlı olacağı söylenebilir.

Çalışmanın, geleceğe yönelik yapılacak çalışmalarda aynı ya da farklı ağırlıklandırma ve sıralama yöntemleri tercih edilerek, aynı ya da farklı uygulama alanlarında karşılaştırmalı analizler yapılabilmesi açısından ayrı bir bakış açısı sunacağı ve literatüre katk1 yapacağı düşünülmektedir.

\section{Kaynaklar}

Abdullah, L. And Otheman, A. (2013). A New Entropy Weight For Sub-Criteria İn Interval Type-2 Fuzzy Topsis And Its Aplication, I.J. Intelligent Systems And Aplications, 02, 25-33.

Akçakanat, Ö.; Eren, H.; Aksoy, E. ve Ömürbek, V. (2017). Bankacılık Sektöründe Entropi Ve Waspas Yöntemleri İle Performans 
Değerlendirmesi, Süleyman Demirel Üniversitesi İktisadi ve İdari Bilimler Fakültesi Dergisi, Cilt: 22, Say1:2, 285-300.

Akgül, Y., (2019). Çok Kriterli Karar Verme Yöntemleriyle Türk Bankacılık Sisteminin 2010-2018 Yılları Arasındaki Performansının Analizi, Finans Ekonomi ve Sosyal Araştırmalar Dergisi, Cilt:4, Sayı:4, 567-582.

Aldemir, A. (2018). Türkiye'deki Mevduat Bankalarının Çok Kriterli Karar Verme Yöntemi İle Analizi, Yüksek Lisans Tezi, İstanbul.

Altemur, N., Çevik, M., ve Karaca, S.S. (2019). Bist 30 Endeksinde İşlem Gören Ticari Bankaların Topsıs Yöntemi İle Finansal Performans Analizi, Uluslararası Issletme, Ekonomi ve Yönetim Perspektifleri Dergisi, Yı1: 4 Cilt: 3, 63-73.

Altunöz, U. (2017), The Analysing Of The Financial Performance Of Banks By Using Fuzzy Ahp And Fuzzy Moora Approaches: Case Of Turkısh Banks, Route Educational And Social Science Journal, 116-132.

Bağcı, H. (2013). Ticari Bankalar İle Katılım Bankalarının Kârlılık Performanslarının Topsis Yöntemi İle Karşılaştırılması, Yüksek Lisans Tezi, İzmir.

Cheng, M. F. and Wang, R. T. (2001). Considering The Financial Ratios On The Performance Evaluation Of Highway Bus Industry, Transport Reviews, Vol:21, No:4, 449-467.

Çalışkan, E. ve Eren, T. (2016). Bankaların Performanslarının Çok Kriterli Karar Verme Yöntemiyle Değerlendirilmesi, Ordu Üniversitesi Bil. Tek. Derg., Cilt:6, Say1:2, 85-107.

Dağdeviren, M., Yavuz, S., ve Kılınç, N. (2009). Weapon Selection Using The Ahp And Topsis Methods Under Fuzzy Environment, Expert Systems With Aplications, Cilt:36, Say1: 4, 8143-8151.

Demireli, E. (2010). Topsıs Çok Kriterli Karar Verme Sistemi: Türkiye'deki Kamu Bankaları Üzerine Bir Uygulama, Girişimcilik ve Kalkınma Dergisi, (5:1),101-112.

Dinçer, H. ve Görener, A. (2011). Performans Değerlendirmesinde Ahp - V1kor Ve Ahp - Topsıs Yaklaşımları: Hizmet Sektöründe Bir Uygulama, Journal Of Engineering And Natural Sciences, Sigma 29, 244-260.

Dinçer, H., ve Görener, A. (2011). Analitik Hiyerarşi Süreci Ve Vıkor Tekniği İle Dinamik Performans Analizi: Bankacılık Sektöründe Bir Uygulama, İstanbul Ticaret Üniversitesi Sosyal Bilimler Dergisi, Y11:10, Say1:19, 109127.

Gazel, Y. (2019). Türkiye'de Faaliyet Gösteren Ticari Bankaların Çok Kriterli Karar Verme Yöntemlerine Göre Performanslarının Siralanması, Yüksek Lisans Tezi, Eskişehir. 
Entropi Temelli TOPSIS ve VIKOR Yöntemleri ile Bankacıllk Sektöründe Finansal Performans Değerlendirmesi

Kandemir, T., ve Karataş, H. (2016). Ticari Bankaların Finansal Performanslarının Çok Kriterli Karar Verme Yöntemleri İle İncelenmesi: Borsa İstanbul'da İşlem Gören Bankalar Üzerine Bir Uygulama (20042014), Insan Ve Toplum Bilimleri Araştırmaları Dergisi, Cilt: 5, Sayı: 7, 1766-1776.

Opricovic, S., and Tzeng, G.H. (2004). "Compromise Solution By Mcdm Methods: A Comparative Analysis Of Vikor And Topsis", European Journal Of Operational Research 156 Pp., 445-455.

Opricovic, S., and Tzeng, G. H. (2007). Extended Vikor Method İn Comparison With Outranking Methods. European Journal Of Operational Research $178,514-529$.

Ömürbek, N., Karaatll, M., ve Yetim, T. (2014). Analitik Hiyerarşi Sürecine Dayalı Topsis Ve Vikor Yöntemleri İle Adım Üniversitelerinin Değerlendirilmesi, Selçuk Üniversitesi Sosyal Bilimler Enstitüsü Dergisi, Dr. Mehmet Yıldız Özel Sayıs1, 189-207.

Ömürbek, N., Karaatlı, M., ve Balc1, H. F. (2016). Entropi Temelli Maut Ve Saw Yöntemleri İle Otomotiv Firmalarının Performans Değerlemesi, Dokuz Eylül Üniversitesi, Iktisadi Ve İdari Bilimler Fakültesi Dergisi, Cilt: 31, Say1: 1, 227-255.

Özel, I. (2016). Türkiye'de Faaliyet Gösteren Mevduat Bankaların Finansal Performanslarının Topsis Yöntemiyle Analizi, Yüksek Lisans Tezi, İzmir.

Özgüven, N. (2011). Kriz Döneminde Küresel Perakendeci Aktörlerin Performanslarının Topsıs Yöntemi İle Değerlendirilmesi, Atatürk Üniversitesi İktisadi Ve İdari Bilimler Dergisi, Cilt: 25, Say1: 2, 151-162.

Özkan, G. (2017). Türkiye'de Halka Açık Özel Sermayeli Ve Kamu Sermayeli Ticaret Bankaları'nın Performanslarının Topsıs Yöntemi İle Analizi, Alanya Akademik Bakış Dergisi, Cilt: 1, Sayı: 1, 47-59.

Özkan, T. (2019). Bıst'te İşlem Gören Mevduat Bankalarının Topsıs Yöntemiyle Finansal Performanslarının Değerlendirilmesi, Bingöl Üniversitesi Sosyal Bilimler Enstitüsü Dergisi, Yıl: 9, Cilt: 9, Sayı: 18, 815-835.

Tezergil, S. A. (2016), Vikor Yöntemi İle Türk Bankacılık Sektörünün Performans Analizi, Marmara Üniversitesi İktisadi Ve İdari Bilimler Dergisi, Cilt 38, Sayı 1, Issn: 2149-1844, 357-373.

Topak, M. S., ve Çanakçıŏlu M. (2019). Banka Performansının Entropi Ve Copras Yöntemi İle Değerlendirilmesi: Türk Bankacılık Sektörü Üzerine Bir Araştırma, Mali Çözüm(İsmmmo), 29(154), 107-132.

Wang, T.C., and Lee, H.D. (2009). Developing A Fuzzy Topsis Approach Based On Subjective Weights And Objective Weights. Expert Systems With Applications, 36 (5), 8980-8985.

Yakut, E. (2019). Entropi Temelli Topsis Yöntemi İle Mevduat Bankası Seçimine 
İlişkin Performans Değerlendirmesi, Teorik Ve Ampirik Perspektifte Seçilmiş Finans Konuları, Editör: Eray Gemici, Nobel Bilimsel Eserler, 195-214.

Yakut, E., ve Kuru, Ö. (2019). Türkiye'deki Mevduat Bankalarının Finansal Etkinliklerinin Veri Zarflama Analizi İle Ölçülmesi, C5.0 Ve Cart Algoritması İle Karar Ağaçlarının Oluşturulması: 2009:2017 Dönemi, Gazi Kitabevi, Ankara.

Yalçıner, D., ve Karaatlı, M. (2018). Mevduat Bankası Seçimi Sürecinde Topsıs Ve Electre Yöntemlerinin Kullanılması, Süleyman Demirel Üniversitesi İktisadi Ve İdari Bilimler Fakültesi Dergisi, Cilt: 23, Sayı: 2, 401-423.

Yamaltdinova, A. (2017). Kurgızistan Bankalarının Finansal Performanslarının Topsıs Yöntemiyle Değerlendirilmesi, Internatıonal Review Of Economic Sand Management, Irem, 5 (2), 2017, 68-87.

Yang, Y. P. O. (2009). Shieh, H. M., And Leu, J. D., A Vikor-Based Multicriteria Decision Method For Improving Information Security Risk. International Journal Of Information Technology \& Decision Making 8, 267-287.

Yılmaz, Ö. (2012). Öğrencilerin Üniversite Tercihini Etkileyen Kriterlerin Belirlenmesinde Analitik Hiyerarşi Proses Uygulaması Ve Süleyman Demirel Üniversitesi Örneği, Yüksek Lisans Tezi, Isparta.

Internet Kaynakları

www.tbb.org.tr/tr/bankacilik/banka-ve-sektor-bilgileri/istatistiki-raporlar/59 $13 / 10 / 2019$

www.borsaistanbul.com/borsa_uyeleri/uye-bilgileri?g=3 13/10/2019 